\title{
Original article \\ Metabolic effects of a caffeinated sports drink consumed during a soccer match
}

\author{
Ana Paula Muniz Guttierres \\ Rio de Janeiro State University, Brazil \\ Rita de Cássia Alfenas \\ Karolina Gatti \\ Federal University of Viçosa, Brazil \\ Jorge Roberto Perrout Lima \\ Federal University of Juiz de Fora, Brazil \\ Ângela Antunes Silva \\ Antônio José Natali \\ João Carlos Bouzas Marins \\ Federal University of Viçosa, Brazil
}

\begin{abstract}
The purpose of this study was to verify the effect of the intake of a caffeinated sport drink (CAFD) compared to a commercial carbohydrate drink (CHOD) on biochemical parameters and rate of perception exertion in youth soccer players. The experiment was setup in a double-blind crossover design where athletes consumed $5 \mathrm{~mL} . \mathrm{Kg}^{-1}$ body weight (BW) before the game and $3 \mathrm{~mL} . \mathrm{Kg}^{-1} \mathrm{BW}$ every 15 minutes during the game. Intake of the CAFD resulted in increased blood glucose (BG) and blood lactate (BL) levels and average of maximum heart rate compared to consumption of the CHOD $(p=0.01)$. No difference was observed in the other variables. CAFD promoted greater plasmatic concentration of BG and BL compared with the CHOD. The CAFD did not increase the mobilization of free fatty acids, did not alter the plasma potassium concentration and was not able to reduce subjective perceived exertion.
\end{abstract}

Keywords: caffeine, sport drink, glycemia, lactate, hydration

Resumo- -Efeitos metabólicos de uma bebida esportiva cafeinada consumida durante uma partida de futebol." O objetivo deste estudo foi verificar o efeito da ingestão de uma bebida esportiva cafeinada (CAFD) em comparação a uma bebida carboidratada comercial (CHOD) sobre parâmetros bioquímicos e a taxa de percepção de esforço em jogadores de futebol categoria juvenil. O desenho experimental foi duplo-cego cruzado, onde os atletas consumiram $5 \mathrm{~mL} \cdot \mathrm{Kg}^{-1}$ de peso corporal (PC) antes do jogo e $3 \mathrm{~mL} \cdot \mathrm{Kg}^{-1} \mathrm{PC}$ a cada 15 minutos durante o jogo. A ingestão de CAFD resultou no aumento da glicemia (GS) e do lactato sanguíneo (LS) e do valor médio da frequência cardíaca máxima em relação ao consumo do CHOD $(p=0,01)$. Nenhuma diferença foi observada nas outras variáveis. CAFD promoveu maior concentração plasmática de GS e LS em comparação com o CHOD. A CAFD não aumentou a mobilização dos ácidos graxos livres, não alterou a concentração de potássio plasmático e não foi capaz de reduzir a percepção subjetiva do esforço.

Palavras-chaves: cafeína, bebida esportiva, lactato, hidratação

Resumen-"Efectos metabólicos de una bebida deportiva con cafeína consumida durante un partido de fútbol." El objetivo fue verificar el efecto del consumo de una bebida deportiva con cafeína (CAFD) frente a una bebida carbohidratada comercial (CHOD) sobre parámetros bioquímicos y el índice de percepción de esfuerzo percibido en jugadores de fútbol de la categoría juvenil. El diseño experimental utilizado fue de tipo doble-ciego cruzado, donde los deportistas ingieren $5 \mathrm{~mL} . \mathrm{Kg}^{-1}$ del peso corporal (PC) antes del partido y $3 \mathrm{~mL} \cdot \mathrm{Kg}^{-1} \mathrm{PC}$ a cada 15 minutos durante el partido. El consumo de CAFD produjo un aumento en la glucemia (GS) y del lactato sanguíneo (LS) y del valor medio de frecuencia cardiaca máxima frente al consumo de CHOD $(p=0,01)$. No hubo diferencias en las demás variables. CAFD produjo mayor concentración plasmática de GS y LS en comparación con la CHOD. La CAFD no aumento la movilización de ácidos grasos libres, no hubo alteración en la concentración de potasio plasmático y no fue capaz de reducir el índice de percepción de esfuerzo.

Palabras claves: cafeína, bebida deportiva, lactato, hidratacióneres 


\section{Introduction}

Caffeine is part of the pharmacological class of methylxanthines and is naturally found in coffee, tea, and cocoa. It was on the list of prohibited substances by the World Anti-Doping Agency (WADA), in the class of stimulants, but since 2004 it is no longer considered a prohibited substance (WADA, 2010). Caffeine is a legal stimulant that is readily available to teenagers. Consumption of caffeine by children and adolescents is increasing, and although the effects of caffeine on adults have been studied, little is known about its effects on children and adolescents (Hughes, Hale, \& Higgins, 1995). Studies have shown positive effects of caffeine on short-term exercise and endurance exercise performance. Researchers have studied the effect intake of different caffeine concentrations on physical performance in acyclic (Paton, Lowe, \& Irvine, 2010; Ping, Keong, \& Bandyopadhyay, 2010; Roberts, Stokes, Trewartha, Doyle, Hogben, et al., 2010) and/or collective sports (McNaughton, Lovell, Siegler, Midgley, Moore, et al., 2008). Other studies have focused on the direct effect of different caffeine concentrations on metabolic parameters such as blood glucose (BG), blood lactate (BL), free fatty acids (FFA) and plasma potassium $(\mathrm{K}+)$ during exercise (Gant, Ali, \& Foskett, 2010; Carr, Dawson, Schneiker, Goodman, \& Lay, 2008).

Caffeine appears in doses ranging from $2 \mathrm{mg}$ to $6 \mathrm{mg}$. $\mathrm{kg}^{-1}$ of body weight (BW) (Astorino \& Roberson, 2010; Gant, Ali, \& Foskett, 2010; Goldstein, Jacobs, Whitehurst, Penhollow, \& Antonio, 2010), reaching maximum doses of $9 \mathrm{mg} . \mathrm{kg}^{-1}$ (Graham \& Spriet, 1991) in various forms of products including capsules (Ping, Keong, \& Bandyopadhyay, 2010) of monohydrated caffeine powder added to carbohydrate drinks (Roberts et al., 2010) and chewing gum (Paton, Lowe, \& Irvine, 2010).

These studies have shown that during exercise, caffeine acts on blood glycemia, increasing its concentration in both aerobic (Hadjicharalambous, Georgiades, Kilduff, Turner, Tsofliou, Pitsiladis et al., 2006) and anaerobic exercise (Woolf, Bidwell \& Carlson, 2008). Other researchers have also shown that caffeine tends of promote an increase in plasma lactate (Carr, Dawson, Schneiker, Goodman, \& Lay, 2008) (Bassini-Cameron, Sweet, Bottino, Bittar, Veiga et al., 2007) and FFA (McNaughton et al., 2008), while $\mathrm{K}^{+}$ generally suffers a decrease after its ingestion (Simmonds, Minahan, \& Sabapathy et al., 2010).

Most studies found in literature were performed with continuous exercise in steady state, in which the energy supplied for exercise was primarily aerobic. When playing soccer, due to its intermittent characteristics of exertion, different metabolic responses can be observed after caffeine consumption.

Caffeine appears to promote positive effects on the specific skills required for soccer, such as vertical jump height (Guttierres, Natali, Alfenas, \& Marins, 2009; Gant, Ali, \& Foskett, 2010), which serves as a good predictor of the explosive force of athletes.
Some authors (Gant, Ali, \& Foskett, 2010) studied the effect of co-ingestion of carbohydrates and caffeine (3.7 $\left.\mathrm{mg} / \mathrm{kg} / \mathrm{BW}^{-1}\right)$ in a hydration beverage consumed by soccer players. It was found that the sport drink consisting of carbohydrates and caffeine significantly increased the vertical jumping ability, sprints and subjective perception of pleasure. However, little is known about the physiological and performance results when carbohydrates and caffeine are ingested simultaneously by teenage players as a form of hydration strategy.

With the large consumption of caffeinated products by young people and the evidence linking the use of caffeine for increasing performance, it is necessary to study the effects of a hydration beverage with characteristics of a electrolyte replenisher on teen soccer players considering the intermittent exeretion characteristic of soccer. Thus, the first objective of this study was to verify the effect of consuming a caffeinated sports drink (CSD) (caffeine concentration $7.2 \mathrm{mg} / \mathrm{Kg} / \mathrm{BW}^{-1}$ ) on biochemical parameters and subjective exertion perception (RPE) among youth soccer players in comparison to a commercial carbohydrate drink (CCD).

\section{Methods}

\section{Participants}

The study included twenty soccer players who were informed of the purpose of the study and voluntarily signed a consent form. The Ethics Committee for Research on Humans of the Federal University of Viçosa, Brazil approved the study. The study complied with all bioethical procedures proposed by the resolution of Brazilian government, the National Health Council (no 196/96). The physical characteristics and maximum $\mathrm{VO}_{2}$ of the participant athletes are described in Table 1.

\section{Experimental design}

In the first stage of the study, the typical caffeine intake of the athletes was investigated. For this purpose, a 3-day food registration protocol ( 2 weekdays and 1 weekend day) was employed to verify the pattern of caffeine usage. These data were checked by a nutritionist. Among the athletes of

Table 1. Physical characteristics and metabolic parameters of the individuals.

\begin{tabular}{lll}
\hline Variables & Mean $( \pm \mathrm{SD})$ & Variation \\
\hline Age $($ years $)$ & $16.1 \pm 0.7$ & $15-17$ \\
Weight $(\mathrm{kg})$ & $66.6 \pm 6.1$ & $55.9-79$ \\
Height $(\mathrm{cm})$ & $174.0 \pm 6.9$ & $162-186$ \\
$3 \Sigma$ skinfolds $(\mathrm{mm})$ & $21.5 \pm 7.7$ & $11.5-35.7$ \\
Body fat $(\%)^{(1)}$ & $8.0 \pm 2.7$ & $3-13.7$ \\
maximum mL VO & $50.1 \pm 3.2$ & $44.7-56.0$ \\
${\text { (kg.min })^{-1}}^{(1)}$ & & \\
(1) Protocol of Jackson \& Pollock (1978); folds = chest, triceps and subscapular. & ${ }^{(2)}$ \\
Protocol of 2400 m of Cooper (Marins \& Giannichi, 1998).
\end{tabular}


the sample, 13 participants were not caffeine consumers ( $<50 \mathrm{mg}$ /day of caffeine), 5 were moderate consumers (50 to $200 \mathrm{mg} / \mathrm{day})$ and 2 athletes were regular consumers of caffeine (200 mg/day) (Chesley, Howlett, Heigenhauser, Hultman, \& Spriet, 1998). The athletes also received verbal and written information to identify the types of caffeinated foods, and they were instructed to avoid them for 48 hours before each soccer match simulation.

In the second part of the study the following factors were evaluated: body composition (Jackson \& Pollock, 1978), maximum oxygen consumption (maximum $\mathrm{VO}_{2}$ ) using Cooper's $2400 \mathrm{~m}$ protocol (Marins \& Giannichi, 2003), and the estimated energy requirement (EER). Each factors was assessed individually according to the recommendations for young people aged 15 to 18 based on a high physical activity factor (Dietary References Intakes, 2002).

In the third step, two soccer matches were simulated with 48-hour interval between them. The matches occurred between 11 a.m. to 1 p.m. Before each match, players received a snack containing $15 \%$ of the calories calculated by the EER with $60 \%$ carbohydrate, $15-20 \%$ protein and $20 \%$ to $25 \%$ lipids (Mcardle, Katch, \& Katch, 2001). The athletes were instructed to refrain from exhaustive training for 48 hours prior to the day of the match.

The experimental was conducted according to a doubleblind crossover model in which another researcher who was not involved in the application of the tests had control over identification of the hydration beverage used. The athletes participated in two soccer matches on two different days and in different situations of ingesting the CSD containing $250 \mathrm{mg} .1^{-1}$ of caffeine or CCD (7\% carbohydrate). Twenty minutes before the match, the athletes ingested $5 \mathrm{ml} . \mathrm{Kg}^{-1}$ of body weight (BW) in fluids and $3 \mathrm{ml} . \mathrm{Kg}^{-1}$ of $\mathrm{BW}$ during every 15 minutes of the game, initiating the intake immediately before the start of each playing time. Each player received nine individual bottles (one bottle with 5 ml.kg-1 of body weight (BW), and 8 with 3 ml. $\mathrm{kg}^{-1}$ of BW) and instructed to consume the whole content. Based on the proposed hydration protocol and due to the fact that the sample was homogeneous, the participants ingested an average of caffeine of $7.2 \mathrm{mg} / \mathrm{Kg} / \mathrm{BW}^{-1}$. The experiment was conducted in August (winter in Brazil). The temperature and relative humidity ( $\mathrm{RH}$ ) of the environment were recorded every 5 minutes. On the days when the CCD and CSD were ingested, environmental conditions were, respectively: $32 \pm 3.5^{\circ} \mathrm{C}$ and $47.8 \pm 8.6 \mathrm{RU}, 32.4 \pm 4.8^{\circ} \mathrm{C}$ and $46 \pm 11.2 \mathrm{RU}$.

\section{Sports drinks}

Two tangerine flavored beverages were tested during the study, with similar color and texture. The CCD drink (7\% of carbohydrates, sodium, chlorine, magnesium, potassium, iron, zinc, manganese, copper, molybdenum, chromium, selenium and vitamin C) was acquired from the domestic market, and the CSD drink (7\% of carbohydrates, sodium, calcium, potassium, selenium, chloride, phosphorus, vitamins $\mathrm{C}$ and $\mathrm{E}$ and $250 \mathrm{mg} . \mathrm{L}^{-1}$ of caffeine anhydride) was elaborated based on possible beneficial effects on sports performance associated with intake of antioxidant compounds (Naziroglu, Kilinc, Uguz, Celik, Bal, et al., 2010; Bobeuf, Labonte, Khalil, \& Dionne, 2010; Rosa, Ribeiro, Pereira, Freymuller, et al., 2009) and caffeine (Giesbrecht, Rycroft, Rowson, \& De Bruin, 2010).

\section{Analysis}

\section{Blood samples}

Blood samples were collected before the game and during the last 12 minutes of each half. Thus sampling started at 38 minutes of each half and each half lasted 50 minutes. Groups of four players were formed, two from each team that would always ; eave the game in the same order to draw blood samples with four nurses, one for each player. The match would continue with the remaining players.

Blood samples for blood glucose (BG) analyses (hexokinase method, Bioclin Kit) and blood lactate (BL) (lactate dehydrogenase method, Katal Kit) were collected in $4.5 \mathrm{~mL}$ tubes with fluoride oxalate, and concentrations were determined using the Alizé equipment (Lisabio, France). Blood samples for FFA analysis were collected in serum gel tube $(10 \mathrm{~mL})$ (acyl-CoA synthetase method / acyl-CoA oxidase, Wako) and analyzed by spectrophotometry (Cobas Plus - Minnesota, USA). For $\mathrm{K}^{+}$, blood was collected in $4.5 \mathrm{~mL}$ tubes containing EDTA and analyzed by the selective electrode method (Easy-Lyte, Nashville, USA) using a sample volume of $100 \mu \mathrm{m}$. Analyses of caffeine concentrations in plasma $(1 \mathrm{~mL})$ were performed by high performance liquid chromatography in the AntiDoping Laboratory (LABDOP-LADETEC, UFRJ). For this analyses, blood was centrifuged for 10 minutes at 3,000 $\mathrm{rpm}$ and stored under refrigeration at $40^{\circ} \mathrm{C}$.

\section{Urine samples}

Two urine samples (before and after the match) were collected and stored in a recipient $(60 \mathrm{~mL})$ and urine density was initially measured using an optical refractometer (LF Equipamentos, São Paulo, Brazil), calibrated with deionized water. Urine $\mathrm{pH}$ was measured using a $\mathrm{pH}$ meter (Digimed, São Paulo, Brazil) calibrated at $\mathrm{pH} 4$ and 7. After these analyses, samples were stored in a refrigerated room. The concentration of urinary caffeine was evaluated by High Performance Liquid Chromatography at the LABDOP.

\section{Heart rate}

The heart rate (HR) was monitored during the match at every 5 minutes of the game, using the Polar telemetry system. The maximum HR was calculated (Tanaka, 
Monahan, \& Seals, 2001) and HR percentages were calculated directly based on the maximum heart rate for each athlete during the match (Kesaniemi et al, 2001).

\section{Rate of perceived exertion}

Rate of perceived exertion (RPE) was measured every 5 minutes of game using a numbered scale (Borg, 1982). For this purpose, we developed a bracelet for each player, with the respective scale (6-20 points). Before the match, players were instructed about the correct way to interpret the scale, as a parameter for identification of central and non-peripheral fatigue.

The two games were intended to simulate a real soccer game. Because each game was ssumed to be unique, it was impossible to anticipate its exertion demands. The HR and RPE measurements were used to verify that the two simulations were similar with respect to intensity. Figure 1 shows the chronological order for a collection of variables.

\section{Statistical analysis}

The results were expressed as mean and standard deviations. Significant difference between the two treatments was evaluated using two-way ANOVA for repeated measures, and complemented by the Tukey post hoc test. The level of significance was $p<0.05$. Correlation was calculated using the Pearson correlation model. The data was analyzed using the statistical program Statistica version 6.0.

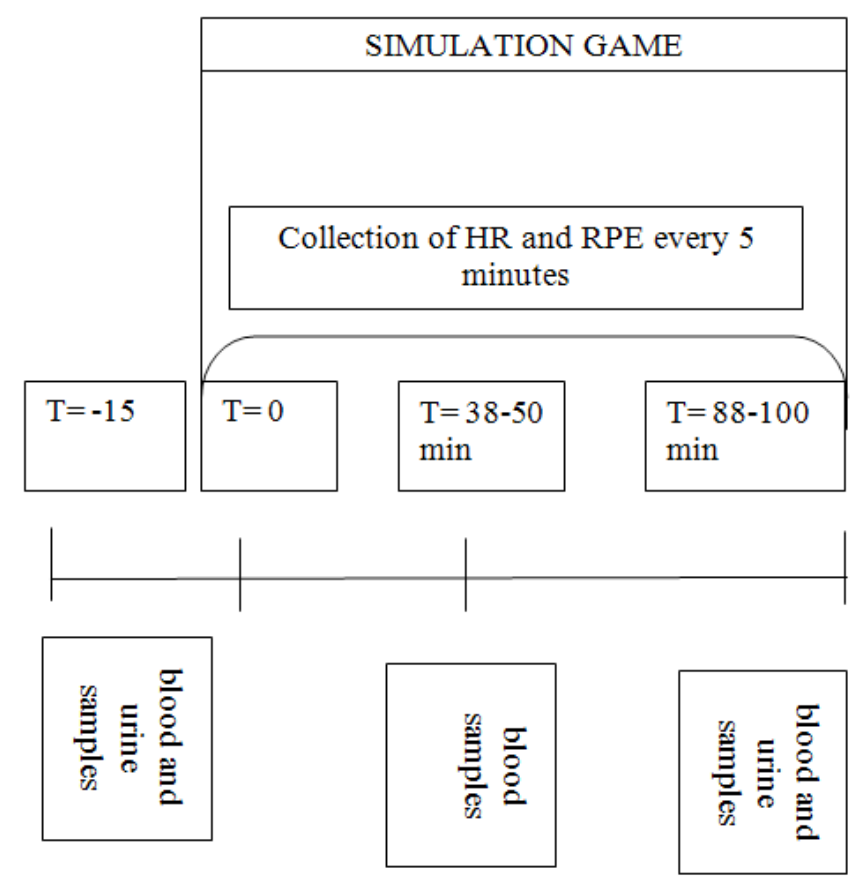

Figure 1. Chronological collection of variables.

\section{Results}

Blood glucose before the soccer matches showed no significant difference between treatments $(p=0.99)$. Regarding the resting values, both the CSD and CCD groups showed that blood samples 2 and 3 increased values compared to blood sample $1(p<0.01)$. There was also a difference between blood sample 2 and blood sample 3 for the CSD and CCD ( $p=0.00$ and 0.04 , respectively). In both cases, there was a reduction in the blood glucose for blood sample 3 compared to blood sample 2 (Figure 2).

At the end of the first half of the match, blood sample 2 of the CSD group showed a higher BG value relative to the CCD treatment $(p=0.01)$, while there was no difference between groups in blood sample 3 ( $p=0.87$ ) (Figure 2).

Regarding lactate values, there was some difference between groups with respect to blood samples 2 and 3, which, in both treatments, were elevated compared to blood sample 1. Comparing the two groups, blood samples 2 and 3 presented higher lactate concentrations in athletes who consumed the CSD (Figure 3).

Regarding plasmatic potassium, there was no difference between groups in blood samples before the match and at the end of the second half of the game $(p=0.99, p=0.47$, respectively). When individuals consumed either CSD or CCD, there was a reduction in plasmatic concentration (both $p<0.01$ ) from the start to the end of the match.

No difference was observed among groups regarding FFA concentration before $(p=0.08)$ and after the matches $(p=0.49)$. There was no statistical difference between the CSD $(p=0.11)$ and CCD groups $(p=0.47)$, from the start to the end of the match.

During the consumption of CCD, there was no presence of caffeine in the urine (UC) or in the blood plasma of the athletes, confirming their complete abstinence of consuming caffeinated products. In the CSD group an increase in UC values was observed between the beginning of the match $\left(0.0 \pm 0.00 \mu \mathrm{g} \cdot \mathrm{mL}^{-1}\right)$ and when the match was

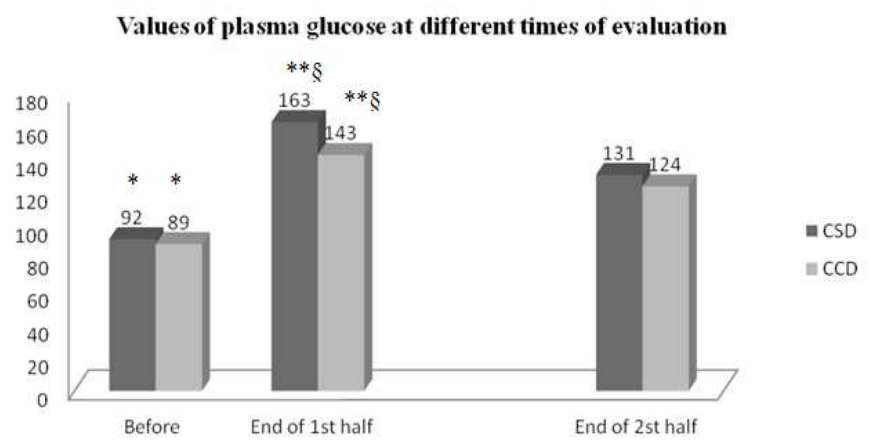

Figure 2. Effect of time on plasma glucose values (mg.dL $\left.{ }^{-1}\right)$ of soccer players who consumed the caffeinated sports drink (CSD) or commercial carbohydrate drink (CCD) during the match. Intragroup comparisons: $*$ Before $\neq$ End of $1^{\text {st }}$ half and End of $2^{\text {nd }}$ half. $* *$ End of $1^{\text {st }}$ half $\neq$ End of $2^{\text {nd }}$ half. Intergroup comparisons: $\S \neq$ End of $1^{\text {st }}$ half $(p<0.05)$. 
Plasma lactate values at different times of evaluation

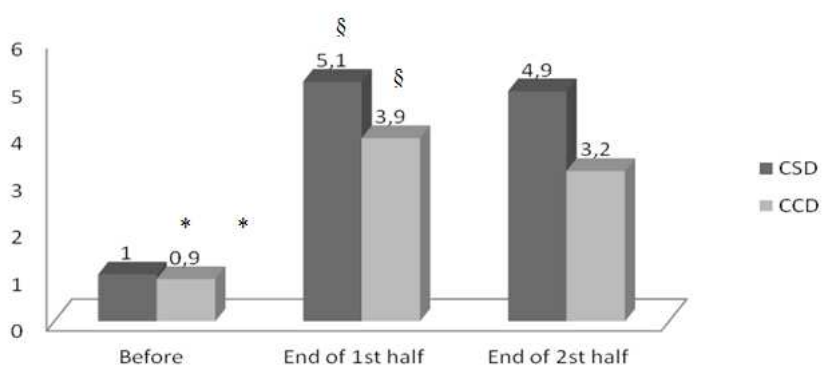

Figure 3. Effect of time on lactate concentration (mmol.L-1) of soccer players who consumed the caffeinated sports drink (CSD) or commercial carbohydrate drink $(\mathrm{CCD})$ during the match. Intra-group comparisons: ${ }^{*}$ Before $\neq$ End of $1^{\text {st }}$ half and End of $2^{\text {nd }}$ half. Intergroup comparisons: $\S \neq$ End of $1^{\text {st }}$ half $(p<0.05)$.

Table 2. Biochemical parameters of individuals.

\begin{tabular}{lllll}
\hline & $\begin{array}{l}\mathrm{PP} \\
\mathrm{mEq} \cdot \mathrm{L}^{-1}\end{array}$ & $\begin{array}{l}\mathrm{FFA} \\
\mathrm{mmol} \cdot \mathrm{L}^{-1}\end{array}$ & $\begin{array}{l}\mathrm{CP} \\
\mu \mathrm{g} \cdot \mathrm{mL}^{-1}\end{array}$ & $\begin{array}{l}\mathrm{UC} \\
\mu \mathrm{g} \cdot \mathrm{mL}^{-1}\end{array}$ \\
\hline CSD before $^{(3)}$ & & & & \\
Mean & 4.33 & 0.52 & 0.0 & 0.0 \\
sd & 0.31 & 0.17 & 0.00 & 0.00
\end{tabular}

$\begin{array}{lllll}\text { CSD during }^{(4)} & & & & \\ \begin{array}{l}\text { Mean } \\ \text { sd }\end{array} & - & - & 1.49 & - \\ & & & 0.57 & \\ \text { CSD after }^{(5)} & & & & \\ \text { Mean } & 3.70 & 0.43 & 6.08 & 1.78 \\ \text { sd } & 0.28 & 0.09 & 0.64 & 2.00\end{array}$

\begin{tabular}{|c|c|c|c|c|}
\hline \multicolumn{5}{|l|}{ CCD before ${ }^{(3)}$} \\
\hline Mean & 4.31 & 0.44 & 0.0 & 0.0 \\
\hline sd & 0.28 & 0.13 & 0.00 & 0.00 \\
\hline $\begin{array}{l}\text { CCD during } \\
\text { Mean } \\
\text { sd }\end{array}$ & - & - & $\begin{array}{l}0.0 \\
0.00\end{array}$ & - \\
\hline \multicolumn{5}{|l|}{ CCD after $^{(5)}$} \\
\hline Mean & 3.83 & 0.48 & 0.0 & 0.0 \\
\hline $\mathrm{sd}$ & 0.26 & 0.26 & 0.00 & 0.00 \\
\hline
\end{tabular}

CSD: Caffeinated sports drink, CCD: Commercial carbohydrate drink, (3) Blood sample before the match, (4) Blood sample after the 1st half, (5) Blood sample after the 2nd half. $\mathrm{PP}=$ Plasma potassium; FFA=Free fatty acids; $\mathrm{CP}=$ Plasma Caffeine; $\mathrm{UC}=$ Urine Caffeine; sd= standard deviation.

over $\left(1.78 \pm 2.00 \mu \mathrm{g} \cdot \mathrm{mL}^{-1}\right)(p<0.01)$. The average total excretion of UC after the match with ingestion of CSD was approximately $3.34 \mu \mathrm{g} \mathrm{mL} \mathrm{m}^{-1}$. There was no correlation between UC and volume of urine produced $(r=-0.20)$.
The values of plasmatic caffeine (PC) $\left(\mu \mathrm{g} \cdot \mathrm{mL}^{-1}\right)$ in the CSD group were: blood sample $1=0.0 \pm 0.0$, blood sample $2=1.49 \pm 0.57$; blood sample $3=6.08 \pm 0.64$. There was an increase $(p=0.05)$ in the PC concentration in blood samplings 2 and 3 when compared to blood sample 1 (before the match) and from sample 2 (end of the first half of the match) to 3 (end of the second half of the match), showing that during the match as the CSD consumption increased, so did caffeine in the blood plasma. However, there was no correlation between the PC and UC ( $r=-$ 0.22 ), and the values of UC and PC showed no correlation with the pattern of caffeine use by the athletes.

Regarding HR, the mean values for the CSD group, including the quick stops for fluids intake, were $158 \pm 8.2$ bpm, which represents $80.6 \%$ of the maximum HR. In the CCD group, the average HR was of $154 \pm 8.9 \mathrm{bpm}$, which represents $74.7 \%$ of the maximum HR.

In the CSD and CCD groups the RPE was, respectively: $7 \pm 1.3$ and $7 \pm 0.49$ at the start of the match; $10 \pm 1.7$ and $10 \pm 1.55$ at end of the first half; and $11 \pm 1.2$ and $10 \pm 1.3$ at the end of the second half. There was a significant increase $(\mathrm{CSD} p=0.003$ and CCD $p=0.012)$ on the RPE from the beginning to the end of the match, however there was no difference between the two beverages $(p=0.145)$ with respect to effect on the RPE. There was no correlation between the RPE and PC concentration in the first and second half of the match $(p<0.05, r=-0.14, r=-0.41$, respectively).

\section{Discussion}

Caffeine consumption by children and adolescents is increasing, and while the effects of caffeine on adults have been studied, little is known regarding its effects on children and adolescents (Hughes, Hale \& Hig, gins, 1995). The present study showed that consumption of a caffeinated sport drink can improve metabolic parameters that can directly influence sports performance of adolescents.

In this study, athletes presented higher values of glycemia with the ingestion of the CSD compared to the CCD, thus agreeing with the results obtained in other studies (Hadjicharalambous et al., 2006; Woolf, Bidwell, \& Carlson, 2008), suggesting a lower glucose utilization during exercise in athletes consuming caffeine. Another proposed mechanism is the increase of sympathetic nervous system activity by caffeine, which promotes secretion of adrenaline and noradrenaline (Davis et al., 2003; Yeo, Jentjens, Wallis, \& Jeukendrup, 2005). These catecholamines may increase glycogenolysis and consequently increase the concentration of plasma glucose during exercise. Researchers suggest that caffeine can stimulate hepatic glycogenolysis, thereby causing an increase in blood glucose (Graham, Helge, MacLean, Kiens, \& Richter, 2000).

Another suggested mechanism for increase blood glucose is resultant of increased glucose uptake by the 
intestine promoted by caffeine intake. Researchers observed that cyclists who ingested a carbohydrate drink supplemented with caffeine $(48 \mathrm{~g} / \mathrm{h}+5 \mathrm{mg} / \mathrm{kg} / \mathrm{h}$, respectively) and exercising at $64 \%$ of the maximum $\mathrm{VO}_{2}$, presented increased intestinal glucose absorption (Yeo et al., 2005). This increase in absorption can be explained by inhibition of the enzyme phosphodiesterase, responsible for inhibiting the AMP-c (Davis et al., 2003). Thus, there is an increase of AMP-c in the cell membranes of the small intestine, increasing the absorption of glucose and increasing blood glucose (Stumpel, Burcelin, Jungermann, \& Thorens, 2001). The behavior observed for blood glucose with the consumption of CSD in this study confirms this positive phenomenon for the athlete.

In the present study, the increase of lactate with the ingestion of CSD compared to CCD has also been observed in other studies (Glaister et al., 2008; McNaughton et al., 2008; Yeo et al., 2005) suggested that the higher concentrations of BL may be a response to the higher rates of muscle glycogen ( $\mathrm{MG}$ ) breakdown when individuals ingested the carbohydrate drink with caffeine, due to the higher secretion of catecholamines (Yeo et al., 2005). However, researchers who studied the effect of caffeine intake on the use of MG during aerobic exercise found no differences between caffeine intake and the placebo (Laurent, Schneider, Prusaczyk, Franklin, Vogel et al., 2000). Other authors also observed that post-exercise caffeine intake results in an increase in the rate of resynthesis of muscle glycogen in the recovery period after strenuous exercise (Pedersen, Lessard, Coffey, Churchley, Wootton, et al., 2008). Therefore, the highest plasmatic concentration of lactate cannot be concretely explained by the greatest breakdown of muscle glycogen in caffeine consumption.

Another explanation for the increase in BL is the ability of caffeine to allow the athlete to achieve a higher exercise intensity (Gant, Ali, \& Foskett, 2010), thus producing higher levels of BL as observed in this study, since the players who ingested CSD performed exercise with higher intensity $(\mathrm{CSD}=80.6 \%$ and $\mathrm{CCD}=74.7 \%$ of maximum heart rate), which may have contributed to the greater concentration of BL in this group.

However, this elevation of BL with the intake of CSD is not related to reduced performance, as observed in other studies (Krustrup, Mohr, Steensberg, Bencke, Kjaer et al., 2006; Carr, Dawson, Schneiker, Goodman, \& Lay, 2008). Scholars have noted that the level of BL in soccer players is not correlated with the concentration of muscle lactate; there is no correlation between this and the drop in performance (Krustrup et al., 2006).

Concerning the blood concentrations of $\mathrm{K}^{+}$in this study, no differences were observed between the treatments. However, researchers have shown that caffeine intake during exercise tends to promote a reduction of plasmatic $\mathrm{K}^{+}$, delaying fatigue. (Simmonds, Minahan, \& Sabapathy, 2010). Nevertheless, it is known that concentrations of $\mathrm{K}^{+}$ can return to resting values 30 seconds after ending the activity (Vollestad, Hallen, \& Sejersted,1994), and in this study the athletes remained off the field for a period of 3 minutes for taking blood samples, so the study presents some limitations for explaining the real action of caffeine on plasma $\mathrm{K}^{+}$.

The CSD beverage was not able to increase the mobilization of FFA, since the FFA concentrations in both treatments were similar, a fact that contradicts some studies (McNaughton et al., 2008). Researchers have shown that these divergences in FFA response to caffeine may be due to differences in body stocks and carbohydrate intake (Weir, Noakes, Myburgh, \& Adams,1987). The first to observe the interaction between diet and caffeine with FFA was Bellet et al. (1965). These authors indicated that a dose of $250 \mathrm{mg}$ of caffeine causes an increase of FFA in 3 hours, however when glucose was ingested simultaneously, the level of FFA was reduced in the first 2 hours after ingestion.

In this study, a possible explanation for the decrease in mobilization of FFA may be due the fact that the CSD beverage promoted higher blood glucose, possibly due to increase of intestinal absorption. The higher blood glucose levels may have stimulated increased secretion of insulin by inhibiting the mobilization of FFA. Caffeine ingestion with glucose increases insulin secretion compared to glucose consumption alone (Graham, Sathasivam, Rowland, Marko, Greer et al., 2001). Another important factor is the bioenergetic dynamics of the soccer match which presents intermittent characteristics with the presence of many jumps and sprints, because the high-intensity physical exertion alone can contribute to depression of plasmatic FFA. Thus, one can assume that the intensity of exercise is a determining factor for the mobilization of FFA independent of caffeine intake.

Despite the acute consumption of CSD (total throughout the match was $23 \mathrm{ml} . \mathrm{kg}^{-1}$ ), caffeine excretion in the urine was little, showing reduced risk of dehydration by increased dieresis (Greer, 2010). This is an important factor since caffeine is not a banned substance by the FIFA, but individuals must take care when consuming caffeine as presented by the CSD. It was also observed in this study that the pattern of caffeine use can influence how this compound can be metabolized, promoting different metabolic responses from its use, since a relationship was found between high concentration of plasma caffeine with a lower habitual intake, and vice versa. These results may explain the observations of researchers stating that ergogenic effects of caffeine are more pronounced in athletes who do not usually consume caffeine (Astorino \& Roberson, 2010). It was observed that CSD stimulated increased HR by an average $4 \mathrm{bpm}$ during exercise; however, this increase does not imply important metabolic considerations, since it is not able to promote significant physiological differences in physical load imposed by exercise.

The action of caffeine on the subjective exertion perception has been studied; however the results are contradictory. As in the present study, Bell and McLellan 
(2003) also found no statistical difference in the RPE when individuals exercised at $80 \%$ of maximum $\mathrm{VO}_{2}$ on the cycle ergometer after ingesting either a placebo diet or caffeine supplemented diet. Furthermore, field studies are needed to elucidate the real effect of caffeine on the subjective exertion perception, since in laboratory conditions several factors that may influence the action of caffeine on the central nervous system such as pre-competitive anxiety and motivation of the supporters are not present.

\section{Conclusion}

This study assessed the effect of consuming a caffeinated sports drink (CSD) (caffeine concentration 7.2 $\mathrm{mg} / \mathrm{Kg} / \mathrm{BW}^{-1}$ ) compared to a commercial carbohydrate drink (CCD) on biochemical parameters and RPE in a youth soccer team. In adolescents, the CSD promoted greater plasmatic concentrations of $\mathrm{BG}$ and $\mathrm{BL}$, compared with the CCD. The CSD did not increase the mobilization of FFA, it did not alter the $\mathrm{K}^{+}$concentration and it was not able to reduce the subjective exertion perception.

Considering the action of the CSD on metabolic parameters and the burden placed on the cardiovascular system, this drink showed to be physiologically safe when consumed by teenage athletes even when subjected to high thermal stress, mainly because it provides greater delivery of glucose to the blood circulation and can thus ensure satisfactory levels of this substrate, delaying the onset of fatigue.

\section{References}

Astorino, T. A. \& Roberson, D. W. (2010). Efficacy of acute caffeine ingestion for short-term high-intensity exercise performance: a systematic review. The Journal of Strength and Conditioning Research 24, 257-265.

Astorino, T. A., Terzi, M. N., Roberson, D. W., \& Burnett, T. R. (2010). Effect of two doses of caffeine on muscular function during isokinetic exercise. Medicine \& Science in Sports \& Exercise, 42, 2205-2210

Bassini-Cameron, A., Sweet, E., Bottino, A., Bittar, C., Veiga, C., \& Cameron, L. C. (2007). Effect of caffeine supplementation on haematological and biochemical variables in elite Soccer players under physical stress conditions. British Journal of Sports Medicine, 41, 523-530.

Bell, D. G., \& McLellan, T. M. (2003). Effect of repeated caffeine ingestion on repeated exhaustive exercise endurance. Medicine \& Science in Sports \& Exercise, 35, 1348-1354.

Bellet, S., Kershbaum, A., \& Aspe, J. (1965). The effect of caffeine on free fatty acids. Archives of Internal Medicine, 116, 750752.

Bobeuf, F., Labonte, M., Khalil, A., \& Dionne, I. J. (2010). Effects of resistance training combined with antioxidant supplementation on fat-free mass and insulin sensitivity in healthy elderly subjects. Diabetes Research and Clinical Practice, 87, 1-3.

Borg, G. A. (1982). Psychophysical bases of perceived exertion. Medicine \& Science in Sports \& Exercise, 14, 377-381.

Carr, A., Dawson, B., Schneiker, K., Goodman, C., \& Lay, B. (2008). Effect of caffeine supplementation on repeated sprint running performance. The Journal of Sports Medicine and Physical Fitness, 48, 472-478.

Chesley, A., Howlett, R. A., Heigenhauser, G. J., Hultman, E., \& Spriet, L. L. (1998). Regulation of muscle glycogenolytic flux during intense aerobic exercise after caffeine ingestion. American Journal of Physiology, 275, R596-603.

Davis, J. M., Zhao, Z., Stock, H. S., Mehl, K. A., Buggy, J., \& Hand, G. A. (2003). Central nervous system effects of caffeine and adenosine on fatigue. American Journal of Physiology Regulatory, Integrative and Comparative Physiology, 284, R399-404.

DRI (2002). Dietary References Intakes for energy, carbohydrate, fibre, fat, fatty acids, cholesterol, protein and amino acids. Institute of Medicine, ed. (Washington Food and Nutrition Board).

Gant, N., Ali, A., \& Foskett, A. (2010). The influence of caffeine and carbohydrate coingestion on simulated Soccer performance. International Journal of Sport Nutrition and Exercise Metabolism, 20, 191-197.

Giesbrecht, T., Rycroft, J. A., Rowson, M. J., \& De Bruin, E. A. (2010). The combination of L-theanine and caffeine improves cognitive performance and increases subjective alertness. Nutritional Neuroscience, 13, 283-290.

Glaister, M., Howatson, G., Abraham, C. S., Lockey, R. A., Goodwin, J. E., Foley, P., \& McInnes, G. (2008). Caffeine supplementation and multiple sprint running performance. Medicine \& Science in Sports \& Exercise, 40, 1835-1840.

Goldstein, E., Jacobs, P. L., Whitehurst, M., Penhollow, T., \& Antonio, J. (2010). Caffeine enhances upper body strength in resistance-trained women. Journal of the International Society of Sports Nutrition, 7, 18.

Graham, T. E., Helge, J. W., MacLean, D. A., Kiens, B., \& Richter, E. A. (2000). Caffeine ingestion does not alter carbohydrate or fat metabolism in human skeletal muscle during exercise. The Journal of Physiology, 529 (3), 837-847.

Graham, T. E., Sathasivam, P., Rowland, M., Marko, N., Greer, F., $\&$ Battram, D. (2001). Caffeine ingestion elevates plasma insulin response in humans during an oral glycemia tolerance test. Canadian Journal of Physiology and Pharmacology, 79, 559565.

Greer, F. (2010). Myth buster: caffeine does not exhibit a diuretic effect during exercise performance. Indian Journal of Medical Research, 132, 11-13.

Guttierres, A. P. M., Natali, A. J., Alfenas, R.C.G., \& Marins, J. C. B. (2009). Ergogenic effect of a caffeinated sports drink on performance in soccer specific abilities tests. Revista Brasileira de Medicina do Esporte, 15, (6), 450-54.

Hadjicharalambous, M., Georgiades, E., Kilduff, L. P., Turner, A. P., Tsofliou, F., \& Pitsiladis, Y. P. (2006). Influence of caffeine on perception of effort, metabolism and exercise performance following a high-fat meal. Journal of Sports Science, 24, 875887.

Hale, K.L., Hughes, J.R., Oliveto, A.H., \& Higgins, S.T. (1995). Caffeine self-administration and subjective effects in adolescents. Experimental and Clinical Psychopharmacology, 4, 364-370.

Jackson, A. S., \& Pollock, M. L. (1978). Generalized equations for predicting body density of men. British Journal of Nutrition, 40, 497-504

Kesaniemi, Y. K., Danforth, E., Jr., Jensen, M. D., Kopelman, P. G., Lefebvre, P., \& Reeder, B. A. (2001). Dose-response issues concerning physical activity and health: an evidence-based symposium. Medicine \& Science in Sports \& Exercise, 33, S351-358. 
Krustrup, P., Mohr, M., Steensberg, A., Bencke, J., Kjaer, M., \& Bangsbo, J. (2006). Muscle and blood metabolites during a Soccer game: implications for sprint performance. Medicine \& Science in Sports \& Exercise, 38, 1165-1174.

Laurent, D., Schneider, K. E., Prusaczyk, W. K., Franklin, C., Vogel, S. M., Krssak, M., Petersen, K. F., Goforth, H. W., \& Shulman, G. I. (2000). Effects of caffeine on muscle glycogen utilization and the neuroendocrine axis during exercise. The Journal of Clinical Endocrinology and Metabolism, 85, 2170-2175.

Marins, J. B., \& Giannichi, R. S. (2003). Avaliação \& Prescrição de Atividade Física - Guia Prático. In Antropometria. Rio de Janeiro: Shape.

Mc Naughton, L. R., Lovell, R. J., Siegler, J. C., Midgley, A. W., Sandstrom, M., \& Bentley, D. J. (2008). The effects of caffeine ingestion on time trial cycling performance. The Journal of Sports Medicine and Physical Fitness, 48, 320-325.

Mcardle, W., Katch, F., \& Katch, V. (2001). Nutrição para o desporto e o exercício. Rio de Janeiro: Guanabara Koogan.

McNaughton, L. R., Lovell, R. J., Siegler, J., Midgley, A. W., Moore, L., \& Bentley, D. J. (2008). The effects of caffeine ingestion on time trial cycling performance. International journal of sports physiology and performance, 3, 157-163.

Naziroglu, M., Kilinc, F., Uguz, A. C., Celik, O., Bal, R., Butterworth, P. J., \& Baydar, M. L. (2010). Oral vitamin C and E combination modulates blood lipid peroxidation and antioxidant vitamin levels in maximal exercising basketball players. Cell Biochemistry and Function, 28, 300-305.

Paton, C. D., Lowe, T., \& Irvine, A. (2010). Caffeinated chewing gum increases repeated sprint performance and augments increases in testosterone in competitive cyclists. European Journal of Applied Physiology, 110, 1243-1250.

Pedersen, D. J., Lessard, S. J., Coffey, V. G., Churchley, E. G., Wootton, A. M., Ng, T., Watt, M. J., \& Hawley, J. A. (2008). High rates of muscle glycogen resynthesis after exhaustive exercise when carbohydrate is coingested with caffeine. Journal of Applied Physiology, 105, 7-13.

Ping, W. C., Keong, C. C., \& Bandyopadhyay, A. (2010). Effects of acute supplementation of caffeine on cardiorespiratory responses during endurance running in a hot $\&$ humid climate. Indian Journal of Medical Research, 132, 36-41.

Roberts, S. P., Stokes, K. A., Trewartha, G., Doyle, J., Hogben, P., \& Thompson, D. (2010). Effects of carbohydrate and caffeine ingestion on performance during a rugby union simulation protocol. Journal of Sports Science, 28, 833-842.

Rosa, E. F., Ribeiro, R. F., Pereira, F. M., Freymuller, E., Aboulafia, J., \& Nouailhetas, V. L. (2009). Vitamin C and E supplementation prevents mitochondrial damage of ileum myocytes caused by intense and exhaustive exercise training. Journal of Applied Physiology, 107, 1532-1538.

Simmonds, M. J., Minahan, C. L., \& Sabapathy, S. (2010). Caffeine improves supramaximal cycling but not the rate of anaerobic energy release. European Journal of Applied Physiology, 109, 287-295.

Stumpel, F., Burcelin, R., Jungermann, K., \&Thorens, B. (2001). Normal kinetics of intestinal glycemia absorption in the absence of GLUT2: evidence for a transport pathway requiring glycemia phosphorylation and transfer into the endoplasmic reticulum. Proceedings of the National Academy of Sciences of the United States of America, 98, 11330-11335.

Tanaka, H., Monahan, K. D., \& Seals, D. R. (2001). Age-predicted maximal heart rate revisited. Journal of the American College of Cardiology, 37, 153-156.

Vollestad, N. K., Hallen, J., \& Sejersted, O. M. (1994). Effect of exercise intensity on potassium balance in muscle and blood of man. The Journal of Physiology, 475, 359-368.

WADA (2010). The 2010 prohibited list international standard. W. A. D. Agency, ed. (Disponível em: http://www.wada-ama.org/ en/World-Anti-Doping-Program/. Acesso em: 05 novembro 2010).

Weir, J., Noakes, T. D., Myburgh, K., \& Adams, B. (1987). A high carbohydrate diet negates the metabolic effects of caffeine during exercise. Medicine \& Science in Sports \& Exercise, 19, 100-105.

Woolf, K., Bidwell, W. K., \& Carlson, A. G. (2008). The effect of caffeine as an ergogenic aid in anaerobic exercise. International Journal of Sport Nutrition and Exercise Metabolism, 18, 412429.

Yeo, S. E., Jentjens, R. L., Wallis, G. A., \& Jeukendrup, A. E. (2005). Caffeine increases exogenous carbohydrate oxidation during exercise. Journal of Applied Physiology, 99, 844-850.

\section{Authors' note}

Ana Paula Muniz Guttierres is with the Laboratórios de Atividade Física e Promoção da Saúde, Instituto de Educação Física, Universidade do Estado do Rio de Janeiro, Rio de Janeiro, RJ and the Departamento de Nutrição e Saúde, Centro de Ciências Biológicas e da Saúde, Universidade Federal de Viçosa, Viçosa, MG.

Rita de Cássia Alfenas and Ângela Antunes Silva are with the Departamento de Nutrição e Saúde, Centro de Ciências Biológicas e da Saúde, Universidade Federal de Viçosa, Viçosa, MG.

Jorge Roberto Perrout Lima is with the Faculdade de Educação Física e Desporto, Universidade Federal de Juiz de Fora, Juiz de Fora, MG.

Karolina Gatti, Antônio José Natali, and João Carlos Bouzas Marins are with the Departmento de Educação Física, Centro de Ciências Biológicas e da Saúde, Universidade Federal de Viçosa, Viçosa, MG.

Este estudo faz parte da dissertação de mestrado de Ana Paula Muniz Guttierres, Universidade Federal de Viçosa, MG, Brasil.

\section{Acknowledgements}

The general coordinator of the Laboratory of Technological Development Support (LADETEC-UFRJ), Dr. Francisco Radler de Aquino Neto, for volunteering to perform the biochemical analyzes.

\section{Correspondence to:}

Ana Paula Muniz Guttierres

Street: São Francisco Xavier, 524, 8th Floor, Room 8133, Block F, Maracanã. 20599-900, Rio de Janeiro, RJ, Brazil

E-mail:paulagutti@gmail.com

Manuscript received on March 27, 2013

Manuscript accepted on May 22, 2013

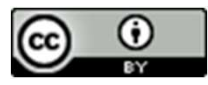

Motriz. Journal of Physical Education. UNESP, Rio Claro, SP, Brazil, eISSN: 1980-6574, is licenced under a Creative Commons License, Version 3.0. 